\title{
化学亡生物

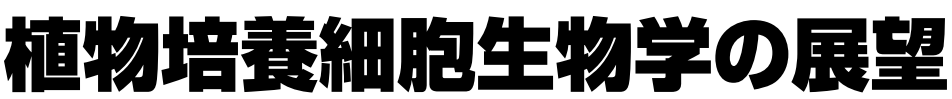 培買細盷によるアルカロイドの生癄への過程
}

文害馆官

山田康之

京都大学・奈良先端科学技術大学院大学名誉教授
私の 40 年にわたる研究の成果を述べる機会を与えられ, 感謝するとともに, 自分の経験を述べることによって若い研 究者の将来の発展のために少しでも役立てばと願っていま す。私の研究内容に関する話は, 半世紀にわたるものであり 記憶が明確でない点もありますが，ご寛容ください。

\section{葉面吸収の研究}

1956 年（昭和 31 年), 私は京都大学農学部農芸化学科 4 回 生となり, 肥料学 (第 3 講座) 研究室に卒業論文作成のため に所属しました. すでに, 両親は亡くなっておりましたので, 私は長兄の世話になっており, 当初からの希望であった文学 部哲学科へ進学することを諦め, 自然科学の内でも牧歌的な 農学部肥料学研究室を選択しました.

肥料学研究室は当時, 田植えをし, また大きなポットにイン ゲン豆や小麦などを土耕・水耕栽培して肥効実験をしていま した. まったくゆったりとした時間経過の中で, 私の大学での 研究生活が始まりました. 教授は後に京大総長になられた故 奥田東教授, 大変な大人物で悠々自適, また学生を叱責され たことは一度もありませんでした。このような環境にて，私 達の研究室から国際的に超一流の学術誌に投稿する考えもあ りませんでした。 おそらく他の研究室の仲間からは少しのん びりした研究者集団であると見られていたかむしれません.

私に与えられた卒業論文課題は「養分の葉面散布に関する 研究」でした。これも, たまたま私が研究室のセミナーで肥 料, 農薬の葉面散布について米国の文献を紹介したのがきっ かけで，それが私の課題になりました. 当時, 放射性同位元 素の ${ }^{32} \mathrm{P}$ が我が国に輸入され始め, 葉面からのリン酸肥料の 吸収速度の指標としてこの ${ }^{32} \mathrm{P}$ を頻繁に用いました。奥田先 生から大学院に進むことのお誘いを受け, 幸いに特別奨学金 もいただけることになり, そのまま肥料学研究室の大学院に 進学しました. 修士論文課題は卒業論文の続きの「養分の葉 面吸収について」でした。相変わらず放射性同位元素の ${ }^{32} \mathrm{P}$ 標識の肥料をつくり, インゲン豆の葉の上に一定量与え, 湿 度を一定にし, 肥料の吸収速度を放射能で調べることでし た. また, 吸収した ${ }^{32} \mathrm{P}$ の分布をラジオオートグラムとして 調べたりしていました.

博士課程に進みますと，私は研究での自主的な思いが強く
なり，葉面吸収の機構を解析的に調べ始めました，葉の一番 外側にはクチクラ膜と称する最外層があり, それを分離し influx を調べることにしました. W. H. Orgell〔'The isolation of plant cuticle with pectic enzymes', Plant Physiol., 30, 78 (1955)〕 と E. A. Baker \& J. T. Martin〔'Cutin of plant surfaces', Nature, 199, 1268 (1963)] の論文を見つけ出し，ク チクラ膜を分離し，その膜の透過性を調べ始めました。 クチ クラ膜のイオン類, 農薬類の influx と efflux の間には差が あり, influx が efflux より大きい值を示しました.すなわ ち，クチクラ膜の透過性は単なる free-diffusion ではなく, その flux に方向性があることを示しました，植物はクチク ラ膜の内側に細胞層があり，その代謝の dynamic force に よって active absorption が生じます。そこで, active absorption を調べるために植物柔細胞をクチクラ膜内の溶液 中に浮遊させ，その細胞の代謝がクチクラ膜の透過性にどの ような効果をもつかを調べることができる植物の葉のモデル をつくりました. すなわち, セルラーゼ, ヘミセルラーゼと ペクチナーゼで葉肉細胞をバラバラにして, クチクラ膜の内 側に浮遊させました。

しかし，微生物の混入をどうしても防ぐことができず，実 験の時間経過とともに微生物増殖の代謝の影響が出てきまし た. そこで，いかに無菌的に植物の柔細胞を得るかが研究の 大切な要因となりました。ここで, 私は遠回りになりますが, 植物の細胞培養により無菌的に細胞を得ることを思いつきま した．現在ではジャーファーメンターで細胞を液体培養する ことなど普通のことですが，当時日本ではきわめて少数の理 学部研究者が試験管内に小さなカルスをつくり，その細胞を 顕微鏡観察するだけでした．とても液体大量細胞培養技術な どはありませんでした.

\section{植物培養細胞への移行}

その当時，私の心を捉えたのは F. C. Steward〔Am. J. Bot., 45, 693 (1958)], F. Skoog〔Symp. Soc. Exp. Biol., 11, 118 (1957)」の細胞培養からの個体再生または器官分化の成功の 報告でした。これらの報告に刺激されて, 外国に行き組織培 養の研究を学ぶことを心に決めました。しかし，当時はまだ 海外に行く研究者は少なく, かつ研究室内で同一テーマで研 
究している人のいる場合はまだ海外との接触は容易でした が，私のように初めて研究する場合には大変困難でした． 特 に肥料学研究室は欧文学術誌に投稿することが少なく, 旧式 のタイプライターが一台あるだけでした.

私は英国のロンドン大学，オーストラリア CSIRO と米国 ミシガン州立大学に勉強したい旨の手紙を出しました. その 当時, 私の英語の論文は 6 報ありましたが，いずれも葉面吸 収に関する論文でした。 ロンドン大学と CSIRO からは本年 は受け入れられないが 2 年後には受け入れるとの返事, 一方 米国ミシガン州立大学の農学部 S. H. Wittwer 教授からは Atomic Energy Commission の grant で滞在費を \$6,000/ 年支払うが渡航費は自分で都合をつけるようにとのことでし た. 私には渡航費などのお金は一切なく，米国のフルブライ 卜財団の試験を受け，幸い合格することができました，私は 博士課程 2 年を中退して助手になっていましたが, きわめて 初期の論文博士の場合で博士論文を作成する前に英語とドイ ツ語の専門科目の試験を受けた記憶があります。学位のない まま奥田先生にミシガン州立大学にて勉強したいとお話しま したら, 先生は休職になるがそれでも良いかとのことでし た. 休職して, 1962 年 (昭和 37 年) 7 月フルブライト研究者 として京都大学の他学部から合格された 4 名の先生方と一緒 にまずハワイにプロペラ飛行機で行き, そこで, 1 週間米国 の日常生活の研修を受け, さらにシアトルでも講習を受けた ように記憶しています.

なんとかミシガン州立大学に到着しましたが，ちょうど夏 休みで教員も学生も少なく, 研究器具もどこにあるのかわか らないまま実験を始めました. Wittwer 教授と J. Bukovac 准教授は私のクチクラ膜の透過性の実験に大変興味をもって おられたので, 実験システムを組み立てて, 直ちに開始しま した. 日本で充分やっていたことですので 1 年目で Plant Physiol. 誌に 3 報, Amer. J. Bot. 誌に 1 報の報文ができまし た. 両先生は大変喜ばれ, 特に Bukovac 准教授は私の帰国 後もクチクラ膜の透過性の研究を続け, 多くの賞を受け活躍 されました.

しかし, 私の本来の目的は植物細胞培養技術の習得でし た. 理学部病理学の Murakishi 教授が細胞培養の研究を行 なっておられることを知り, 2 年目から Murakishi 先生の研 究室で暇を見つけて細胞培養の基本操作を習得いたしまし た. そして, 2 年目から 3 年目で州国するまでの間, 夕バコの 髄組織からのカルス誘導を行ない, カルスから Skoog の報 文に従って茥葉分化, 根分化誘導の練習をしましたが, すべ て寒天培地で液体培養には至りませんでした。

私の 3 年目の滞在中に奥田教授が学部長から京大総長に選 出され, すぐに帰国するようにとの連絡がありました. 滞米 中には, ケネディー大統領の暗殺など大事件がありました が, 米国の科学技術全盛時代で, 日々が本当に楽しく研究も 大変はかどりました。 このまま腆国するのをやめ, 京大を辞 職することも真剣に考えましたが, 1965 年 (昭和 40 年)に帰 国し, 植物栄養学研究室 (旧肥料学研究室) に復職しました. そのとき, すでに私の興味はクチクラ膜の透過性から細胞
培養に移っており, 新しい領域への研究が始まりました。鹵 国後直ちに, 地下の物置部屋を自分達でペンキを塗り, 床に タイルを張り, 雑菌ができるだけ入らない実験室をつくりま した．無論, クリーンベンチなどない時代ですから，微生物 移植用のガラス箱を用いました。 午後の移植は雑菌が入りや すく, 誰も大学に来ない朝 5 時頃ですと, 実験室の空気も動 かないので雑菌の混入が防げました，手伝ってくれる人はい ませんでしたが, ミシガン州立大学大学院博士課程の学生で あったパトリシアと結婚しておりましたので, 家内を実験手 伝いとして器具洗いなどをしてもらっていました。 とにか く, また最初からタバコの髄組織を無菌的に取り出し, カル スをつくり寒天培養を始めました。 この頃は, 植物ホルモン の研究が活発で, オーキシン類濃度やサイトカイニン類濃度 の変化により, カルスの増殖, 器官分化の出現が見られまし たが, 1962 年 Murashige \& Skoog の合成培地が発表され， これによって培地中の天然物をすべて排除することができま した.

当時, 植物の細胞培養の研究を行なっている研究者はまだ きわめて少なく, 20 名くらいだったと思います. 大量液体細 胞培養を行ない分離したクチクラ膜と合わせた生体モデルを つくる吸収実験のことはまだ頭の中にありましたが，科学研 究費取得のこともあり, 細胞培養の研究のほうに移って行き ました。

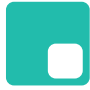

\section{単子葉植物の細胞培養}

日本でまず研究したことは，単子葉植物の細胞培養です． 当時, 世界中で単子葉植物の細胞培養は不可能であることが 通説となっていました. 私は同じ植物の細胞がオーキシン 類, サイトカイニン類の作用により細胞分裂する事実を推察 し, これらの植物ホルモンのきわめて高濃度の培地をつく り, イネ, カラスムギ, オオムギなどの種子からカルス誘導 を行なったところ, 細胞分裂を始め, カルスが生成し, さら に，またそのカルスから個体を再生させることができ，1967 年, 1968 年と続いて Nature 誌に 2 報発表しました（共同研 究者: 西豊行, O. Carter (以下同じ) $)^{(1 \sim 3)}$.

さらに 1985 年には, 裸細胞のイネプロトプラストから個 体再生に成功し, これによってイネ細胞融合, さらにイネの 遺伝子組換えによる品種改良の道が拓けました，このよう に, 他の日本人の研究者の方々との研究成果とも合わせて単 子葉植物の細胞培養, 個体再生の道が世界に先駆けて拓かれ ました（西豊行, O. Cartar, 鹿内利治, 水谷正子).

\section{植物細胞生化学への展開}

このようにして, 私は肥料学から植物栄養学・植物細胞生 化学へと進んでいきました. この当時, 私は「脱分化」,「再 分化」という造語を岩波書店の“科学”(1967 年) に初めて定 義して出しました。それ以来，この言葉は今でも使われてい るようです。 
その後, カルス誘導時に細胞核内クロマチンのタンパク質 とオーキシンの 2, 4-D (2,4-ジクロロフェノキシ酢酸) との複 合体形成を調べた結果, 脱分化に伴って2,4-D が特異的に very lysine-rich histone と複合体形成することなどを明ら かにしました (安田武司, 矢島康夫, 関谷次郎 $)^{(4,5)}$. しかし, 私が属している研究室では私の研究内容があまりにも他の研 究と異なっており，断念せざるを得ませんでした，今になっ て考えると, ともに研究してくれた大学院生諸君のために孤 独になってもこの研究を続行すべきであったかと考えたりし ますが，これは大変難しい点であります.

当時, 私は細胞融合の実験も開始していました. その理由 は, 1969 年ロックフェラー財団がイタリーのミラノ近辺のベ ラジオの別荘に世界各国から十数人の研究者を招待し, プロ トプラスト融合による作物改変の可能性について討論会を開 き，私む日本から一人だけ招待されたことによります．詳細 はScience, 66, 1068-1069 (1969) に記載されましたが, 人数む 限られており, 大変充実した討論の一週間でした。しかし, 当時, 日本の大学は学園紛争真っ只中で, 私もその中にあっ て研究の続行は非常に難しいものでした（T. Eriksson, 原康 弘, 䃘木博昭, Z. Q. Yang, 森川弘道 $)^{(6,7)}$.

\section{培養細胞の機能へテロ性の発見}

1970 年代, いろいろな植物細胞を培養している間に, 私は 培養細胞が必ずしも均一な機能を発現していないことに気づ き始めました. 元来, 植物細胞培養の目的の一つは, 植物個 体の器官機能を排除した培養細胞の均一性にありました。し かし, 私はこのときに, 同一組織由来の培養細胞の中に不均 一性が存在することを見いだしました(8). たとえば，アント シアニン産生の細胞培養でも非常に赤い色素をつくる細胞,

薄赤色の細胞, 白色の細胞ができてきます．私にとってこれ は非常に驚くべきことであり, F. Steward が培養細胞の totipotency (分化全能性) を提唱し, 単一細胞から個体再生能 を示しましたが，私にとっては，これはすべての培養細胞か らではなく，ある特定の細胞がそのような全能性を有してい るという考えに至りました. すなわち, 全能性を有する細胞 は動物細胞の stem cell のような細胞なのかもしれません. しかし, 私はすでに植物の器官分化の系より植物固有の体内 代謝を分化のマーカーとして研究することに焦点を合わせて いました，植物が他の生物と異なる代表的な特徵は, 細胞内 小器官としての葉緑体の形成であり, その代謝機能として光 合成能のあることです。

\section{光独立栄養細胞培養}

そこで，ただちに培養細胞で葉緑体形成をする細胞を選ぶ ことに研究を集中しました。一般に, 培養細胞はショ糖を培 地に加え, 暗所下で培養しますので白色です。たとえ, 明所 下で培養しても緑色化しないのが普通です。植物の形態形成 と光合成機能の発現は相関しています.しかし, 脱分化した
培養細胞で光合成機能をもつ細胞を得ることは過去に成功し ていませんでした，したがって，目的としたことは，脱分化 した個々の細胞が緑化して，葉緑体を有し，光合成機能を保 持していること, すなわち器官, 組織の形態から細胞は脱分 化しているが, 細胞内小器官の葉緑体は発達分化している細 胞を培養することでした，換言すれば，光独立栄養培養細胞 をつくることでオーキシンなどを低濃度にし，かつ培地から ショ糖を除去することでした. 1978 年に夕バコの緑色光独立 栄養液体培養に初めて成功しました (佐藤文彦, 萩森学).こ の細胞が光合成活性をもっていることも確認しました，実際 には, 明所下でカルスを誘導しますと多くの場合, 緑色, 白 色あるいは赤色などの種々の細胞集団が混在してゆきます. ここで, 緑色の濃い細胞を選抜し培養することが重要でし た. その後, この光独立栄養培養細胞の光合成機能について いろいろと研究が続けられました（佐藤文彦，西田晃二郎， 宮地重遠, 竹田恵美, John Fitchen, 中野雄司, 小泉望, 重松 由夫, 室田憲一, 小岩尚志, 北島佐紀人 $)^{(9 \sim 11)}$.

以上に述べてきましたように，個々の培養細胞がその機能 に関して heterogeneous であることの認識と分化の研究を 代謝機能から研究する思考が重なって, それぞれの有用植物 に特異的に産生される二次代謝物質を特に高産生する細胞 を, 機能分化能をもつ培養細胞から選抜することを始めまし た.

\section{二次代謝産物の生化学と分子生物学}

一次, 二次代謝物質は，一般的によ゙の植物にも含まれてい ますが，動物が産生できないビオチンをまず取り上げ，選抜 を開始しました (渡邊克美)。一次代謝産物の代謝制御と二次 代謝産物の代謝制御が本質的に異なることに私は気づきませ んでした，一次代謝はその植物（生物）にとって必須のもの であり，その代謝なしには生きることができません。一方， 二次代謝はその植物（生物）にとって特有の代謝であり, 生 物の生命保持のために必須ではありません. 特に植物の二次 代謝産物はその植物に特有の物質, 色素類, アルカロイド類, テルペノイド類であり，一部では老廃物とさえいわれていま す。それゆえにその代謝産物産生の制御は静的であり, 比較 的容易です. しかし，ビオチンのように植物にとっても補酵 素として必須であり，基本代謝に関与する物質の代謝制御は きわめて困難です。このテーマはあまりにも私の安易な判断 で, 研究した共同研究者に今も申し訳なく思っています.

従来, 植物培養細胞による物質生産にあたっては, 細胞当 たりの有用二次代謝物質産生量が天然の植物個体組織などの 含有量に比べて劣ると見なされていました，しかし，前述の ように細胞塊を構成する個々の培養細胞は，それぞれ物質産 生機能の発現に関してモザイク的な構成をなしており, 細胞 塊の中から物質産生機能の高い細胞を選抜し，それを大量に 培養するならば，植物培養細胞によって特定物質を大量に生 産することが可能であることを予想しました，そこで，有用 二次代謝物質高生産細胞の選抜方法について検討した結果, 
細胞小集塊レベルで選抜する細胞小集塊法と細胞をバラバラ にしたプロトプラストレベルで選抜するプロトプラスト法の 2 つの方法が考え出され, 前者の方法によって植物個体に優 る有用二次代謝物産生機能を発現する培養細胞を得る方法が 確立されました(8). これにより，ハナキリン培養細胞からア ントシアニン (山本好和, 木下靖浩), セリバオウレン培養細 胞からベルベリン (佐藤文彦, 岡田尚輔), タマサキッッ゙ラフ ジ培養根からアロモリン (杉本幸裕), ムラサキ培養細胞から シコニン (藤田泰宏, 田端守, 西荒介), ヒヨス培養根, ドゥ ボイシア培養根からヒオシアミン, スコポラミン, ニコチン など (橋本隆, 中島敬二, 庄司翼), 従来, 植物個体の特定部 位から抽出, 分離されていた有用物質を組織・細胞培養に よって大量につくる道が拓かれたことになり, これらの細胞 選抜法は, 当時, 植物培養細胞による有用物質生産工業化の 基盤を形成するに至りました（日本ペイント, 三井石油化学, 住友化学).

この時点で, 私は培養細胞, 培養根による有用二次代謝産 物としてイソキノリンアルカロイド, ビスベンジールイソキ ノリンアルカロイド, トロパンアルカロイドの生産を目標と した基礎研究にとりかかりました。 過去, イソキノリンアル カロイドの一種であるベルベリンはキハダの樹皮のコルク 層, セリバオウレン, キクバオウレン, コセリバオウレンな よ゙の根茎より抽出, 結晶化されていました. 黄色針状結晶を なすこの化合物は, 黄色ブドウ球菌, 赤痢菌など腸内病原性 細菌に対して殺菌効果を有する重要な局方医薬品で, 最近で は抗炎症作用を有することも報告されています。しかし，こ れらの植物の生育は遅く, キハ夕゙の樹皮はもちろん, オウレ ンは野生の場合 8〜 10 年, 栽培でも 5〜6 年の長年月を要し, 当時, 中国産のオウレンを輸入せざるを得ない状態でした.

佐藤文彦助教授をリーダーとするグループによりセリバオ ウレンの茎から不定根の分化が認められ，この不定根由来の 小組織片から白色と黄色の細胞が得られました. この黄色細 胞を増殖させ, 細胞小集塊選抜を繰り返すことによって, 細 胞増殖速度が速くかつ, アルカロイド呈色反応試薬ドラゲン ドルフ陽性である細胞株を得ました。このアルカロイドの主 成分がベルベリンであることが精製したアルカロイドの融 点, UV, IR, NMR, MS スペクトルで確認されました. このべ ルベリン高産生細胞株は最高含量乾物重当たり $13 \%$ に及び ました(12〜14).

その後, 私が教授を辞し, 奈良先端科学技術大学院大学教 授に赴任した後, 佐藤文彦教授らは私の仕事を継承して, こ の材料を使ってベルベリン生合成の 9 段階の反応のうち 7 段 階の酵素遺伝子, さらには関連する 5 酵素遺伝子をはじめて 単離同定し，それぞれの酵素の性質を明らかにしました。ま た, 佐藤教授らはベルベリンを産生しないハナビシソウ細胞

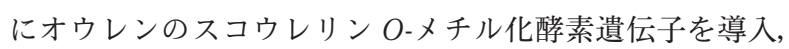
世界で初めてベルベリン型アルカロイド産生細胞を創出し, イソキノリンアルカロイド生合成系の量的・質的改変の技術 基盤を確立しました。 さらに最近, 熊谷英彦京都大学名誉教 授らと共同研究を行ない, 微生物にイソキノリンアルカロイ
ド生合成系の遺伝子を導入し，微生物によるアルカロイド産 生に成功しています.

この私の京大から奈良先端科学技術大学院大学への移籍の 頃, 一つのうれしい出来事が起こりました. 平成 11 年の米国 立科学アカデミーの外国人会員に選出されたことです。私は 当時 19 名の日本人会員の一人になれたことを感謝し，米国 人の妻に少しお返しができたのではないかと考えました（図 1).

トロパンアルカロイドは二環式アミン構造のトロパン環を 有する重要な植物二次代謝産物の一つです。これらのうち七 ヨシアミンやスコポラミンなどはヒヨスなどの数種のナス科 植物に含まれ, 副交感神経末梢制御作用をもち, 医薬品とし て広く実用化されています。特に，スコポラミンは最も重要 なアルカロイドとみなされていますが, チョウセンアサガ オ，ハシリドコロ，ベラドンナなどにおいては多くの場合， 主な最終産物は $[S]$-ヒヨシアミンであってスコポラミンでは ありません。 しかも，植物体内におけるヒヨシアミンからス コポラミンへの変換過程は不明のままでした。一般に, トロ パンアルカロイド生合成経路に関してはこれまで, 植物個体 への放射性同位体投与実験などの結果から，オルニチンを出 発物質として生合成されたトロピンがフェニルアラニン由来 のトロパ酸と脱水縮合して $[S]$-ヒヨシアミンを生成し, 次い でエポキシ化されてスコポラミンが生合成されるものと推定 されていました．現実には一部の化合物の同定が行なわれて いるだけで, 生合成過程における個々の物質変換反応とそれ らに関わる酵素的知見は明らかになっていませんでした。 そ こで, 材料としてヒヨス, ドゥボイシア両植物の培養細胞か ら分化した培養根の選抜により，スコポラミン生合成能の高 い培養根系を用いました，橋本隆博士をリーダーとして生化 学, 分子生物学の学問領域を広く活用して, この課題に取り 組み, オルニチンからスコポラミンに至るトロパンアルカロ イドの全生合成経路を確認し，さらに，それぞれの物質変換

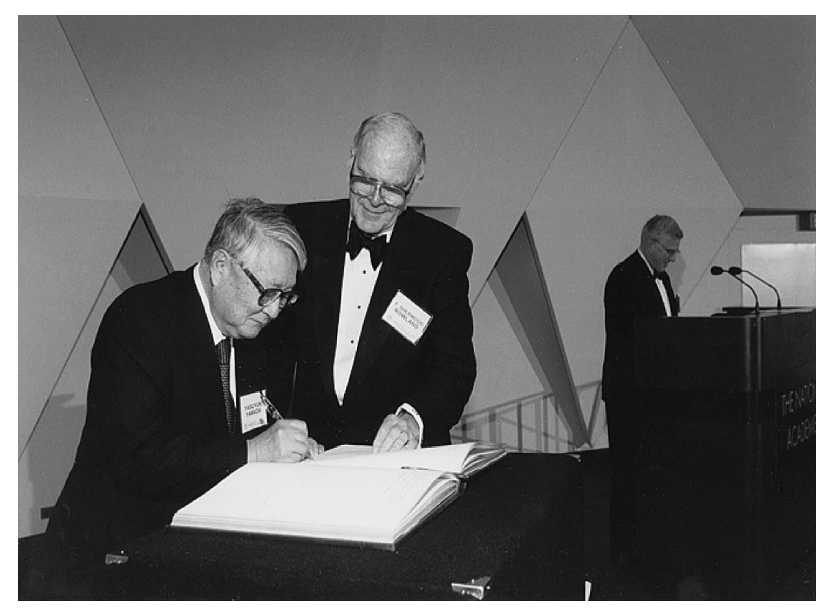

図 1 -1999 年（平成 11 年） 米国立科学アカデミー外国人会 員就任式にて署名する筆者

立会人はノーベル賞受賞者ローランド博士, 後ろは米国立科学 アカデミー院長 


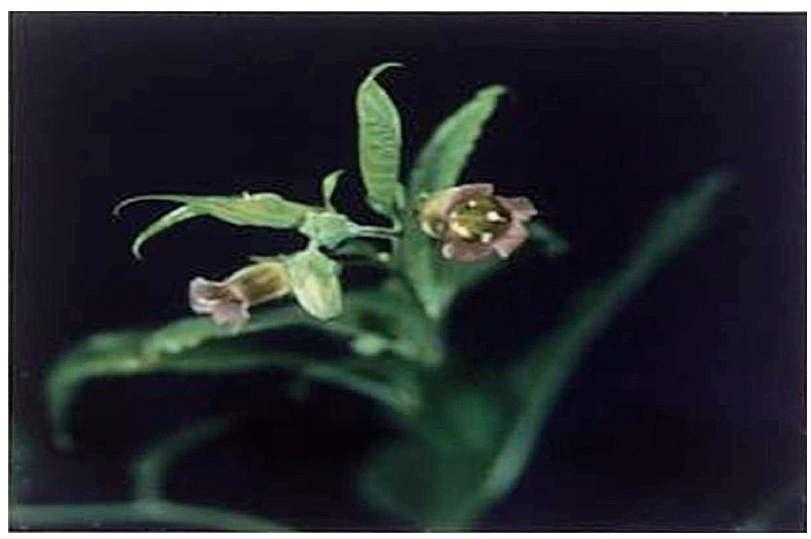

図 2 『 ヒス植物のヒヨシアミンからスコポラミンへの変換 遺伝子を導入したベラドンナ植物

茥葉中にはスコポラミンのみが含まれている.

反応機構を解明，証明することができました（橋本隆， Edward Leete, 遠藤剛, 村瀬淳子, 益満行広, 松田潤, 中島敬 二，行宗敬人，D. J. Yun，日比徳浩).

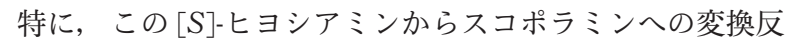
応はきわめて重要であり, その反応機構はまったく不明のま まで，わずかに中間体として，6 $\beta$-ヒドロキシヒオシアミンが 同定されているに過ぎませんでした。私達はスコポラミン高 産生ヒヨス培養根を用い $[S]$-ヒヨシアミンが 2-オキソグル タール酸依存型ジオキシゲナーゼによって, $6 \beta$-ヒドロキシ ヒオシアミンに変換されることを初めて明らかにし, 本オキ シゲナーゼは単一酵素として精製された後ヒオシアミン $6 \beta$ ヒドロキシラーゼと命名されました。さらに，この酵素が $6 \beta$-ヒドロキシヒオシアミンにも作用して, 脱水素最終産物 としてスコポラミンを生合成するというきわめて注目すべき 事実が発見されました. さらに本酵素は, 非天然の 6,7-デヒ ドロヒオシアミンをもスコポラミンに変換する多機能性の酵 素であることが橋本隆博士らの努力により明らかになりまし た(15〜19).

本酵素の発見により，医薬品として最も重要なアルカロイ ドであるスコポラミンの生合成反応機構が明白になったばか

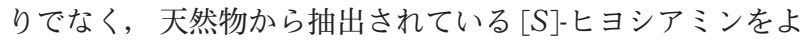
り重要なスコポラミンに変換させることが可能となりまし た. さらに, 本酵素の遺伝子を解析し, さらにその遺伝子を $[S]$-ヒヨシアミンを主最終産物とするベラドンナ組織に形質 転換してこの組換え細胞から個体再生しました。この遺伝子 組換えベラドンナ植物はアルカロイドを茥葉に集積します が，そのアルカロイドはすべてスコポラミンであり，植物本 来の産生するアルカロイドをより重要なアルカロイドに変換 するアルカロイド産生植物が初めて創出されました（橋本 隆, D. J. Yun)（図 2) ${ }^{(20 \sim 23) . ~}$

\section{おわりに}

以上，私達研究室の行なってきた培養細胞によるアルカロ イドの生産への過程を述べてきました。しかし，この鏑矢に なったのは私が米国で多くの人から細胞培養の基本を習った ことにあると思います，高齢になって振り返りますと，科学 者として将来たどる路程は，若いときの研究に対する強い興 味とさらに刺激とそれに応ずるあくなき基礎知識の獲得の情 熱によって決定されると考えています。その間には，本当に 喜びもあり，悲しみもありましたが，これらの喜びも悲しみ もともに分かち合う共同研究者に恵まれていたことは非常に 幸いなことだったと感謝いたしております。研究室の強い絆 があってこそ，これらの苦難を乗り越えて頑張ることができ たのではないかと思い出されます。文中にそれぞれの研究課 題の共同研究者名を記載し，心から感謝を呈しております. 私の現職時代の研究室と現在の研究室のあり方は大変異なっ ているように思います。いずれが良いかはわかりませんが, 私の若い時代には自己に対する誇りと強い意志が現在に比べ てもっとあったように思います。しかし，世の中がいかに移 り変わっていっても, 我々, 人間としての志は変わらないと 思います。

最後になりましたが，現役の研究者の皆様がますます，研 鑽に励まれ，強い意志をもって，立派な研究成果を上げられ ることを願い，かつ現在までの私をご支援くださった多くの 諸先輩，同僚また共同研究者の仲間に深甚なる謝意を呈しま す。また，本稿の執筆中，筆者は入退院を繰り返したが，終 始御支援を給りました京都大学村田幸作教授に心から感謝い たします。

\section{文献}

1) Proc. Japan Acad., 43, 156 (1967).

2) Nature, 214, 1029 (1967).

3) Nature, 219, 508 (1968).

4) Biochem. Biophys. Res. Commun., 40, 649 (1970).

5) Phytochemistry, 14, 1939 (1975).

6) Phytochemistry, 18, 423 (1979).

7) Plant Physiol., 65, 1099 (1980).

8) Theor. Appl. Genet., 61, 113 (1982).

9) Plant Cell Physiol., 19, 691 (1978).

10) Plant Physiol., 97, 844 (1991).

11) J. Mol. Biol., 286, 1137 (1999).

12) Phytochemistry, 27, 979 (1988).

13) Proc. Natl. Acad. Sci. USA, 86, 534 (1989).

14) Agric. Biol. Chem., 54, 2189 (1990).

15) Proc. Natl. Acad. Sci. USA, 89, 11799 (1992).

16) Phytochemistry, 32, 659 (1993).

17) Phytochemistry, 34, 949 (1993).

18) J. Biol. Chem., 269, 11695 (1994).

19) Annu. Rev. Plant Physiol. Plant Mol. Biol., 45, 257 (1994).

20) Biochem. Biophys. Res. Commun., 211, 909 (1995).

21) The Plant Cell, 9, 1673 (1997).

22) Plant Mol. Biol., 40, 141 (1999).

23) J. Biol. Chem., 274, 16563 (1999). 